\title{
TORAJYVÄSIENEN, CLAVICEPS PURPUREA (FR.) TUL.:N SKLEROTIOIDEN ITÄMISESTÄ
}

\author{
ANNA-LiISA RUOKOLA \\ Helsingin yliopiston kasvipatologian laitos, Viikin koetila \\ Saapunut 5. 9. 1957
}

\section{Johdanto}

Vuosina 1952-1955 suoritettiin Helsingin yliopiston Viikin koetilalla torajyvän viljelykokeita (vrt. 17). Kokeiltavina olleiden torajyväkantojen sklerotiot olivat runsasalkaloidisia $(20)$ ja siis ihmisille ja eläimille myrkyllisiä. Niinpä oli aiheellista tutkia paitsi sienen aiheuttamaa sekundäärisaastuntaa rukiin talousviljelmissä (vrt. 18), myös koteloitiöiden välityksellä tapahtuvaa sienen suvulliseen lisääntymiseen perustuvaa tartuntaa.

Syksyllä maahan pudonneissa torajyvissä tapahtuu talven aikana muutoksia, joiden seurauksena torajyvät seuraavana kesänä suotuisissa olosuhteissa itävät muodostaen alustapahkoja (stromia; kuva 1). Niiden pallomaisessa päässä kehittyvät kotelopullot, ja näissä muodostuvat koteloitiöt saastuttavat rukiin sekä eräiden heinälajien kukintoja. Torajyvien on todettu itävän myös laboratoriossa, edellytettynä, että ulkonaiset olosuhteet on järjestetty soveliaiksi $(1,4,6,10,12$, 19, 22). Myös kasvipatologian laitoksessa suoritettiin vastaavanlaisia torajyvien itämistä koskevia tutkimuksia.

Torajyvien idätyskokeissa käytetty kotimainen torajyväkanta eristettiin Viikin koetilalla Ensi-rukiin tähkistä v. 1950 poimituista sklerotioista. Kokeissa mukana olleet ulkomaiset torajyväkannat lähetti professori K. MoTHEs Saksasta, Gaterslebenistä. Torajyväkannoista käytetään (vrt. 17) seuraavia lyhennyksiä: $D_{1}$ (Gatersleben IV, Saksa); $D_{4}$ (X b, Saksa); F (Viik, Suomi).

Koesarjoja suoritettiin viisi: 1) 9. 10. 1952-17. 1. 1953; 2) 6. 8.-5. 10. 1953; 3) 6. 5. -27. 7. 1953; 4) 26. 6.-12. 9. 1953; 5) 8. 10. 1953-28. 6. 1954. Neljässä ensimmäisessä koesarjassa (laboratoriossa) tutkittiin vuoden 1952, yhdessä niistä (koesarja 2) lisäksi vuoden 1953 torajyväsatoa. Koesarja 5 suoritettiin kasvipatologian laitoksen koekentällä. Sitä paitsi tehtiin havaintoja syksyllä maahan varisseiden torajyvien itämisestä seuraavana keväänä. Idätyskokeissa kiinnitettiin huomiota myös torajyvässä esiintyviin sienilajeihin, joilla voi olla vaikutusta torajyvän itämiseen. 


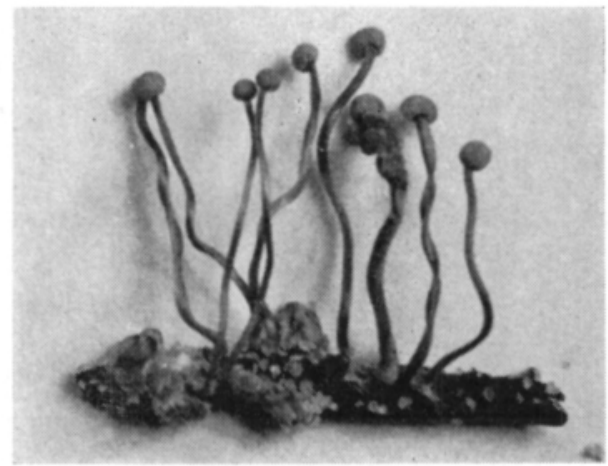

Kuva 1. Itänyt $\mathrm{D}_{1}$-torajyväkannan sklerotio.

Abb. 1. Das gekeimte Sklerotium des Mutterkornstammes $D_{1}$.

\section{Kylmäkäsittelyajan pituuden ja -lämpötilan vaikutus torajyvän itämiseen}

Torajyvät kylvettiin kvartsihiekalla puoleksi täytettyihin Petrin maljoihin. Ennen kokeen alkua sklerotiot huolellisesti pestiin vedessä; hiekka-alustat kostutettiin ja steriloitiin. Petrin maljoihin kylvettyjen torajyvien kylmäkäsittely tapah-

Taulukko 1. F- ja $\mathrm{D}_{1}$-torajyväkantojen sklerotioiden itäminen vv. 1952_-1953 (koesarja 1). Sklerotioiden luku koejäsentä kohden $50 \mathrm{kpl}$. Sklerotioiden kylmäkäsittely $1^{\circ} \mathrm{C}$, idätyslämpötila $18.7^{\circ} \mathrm{C}$.

Tabelle 1. Das Keimen von Sklerotien der Mutterkornstämme $F$ und $D_{1}$ in den Jahren $1952-1953$ (Versuchsreihe 1). Anzahl der Sklerotien je Versuchsglied 50 St. Kaltbehandlung der Sklerotien $1^{\circ} \mathrm{C}$, ihre Keimungstemperatur $18.7^{\circ} \mathrm{C}$.

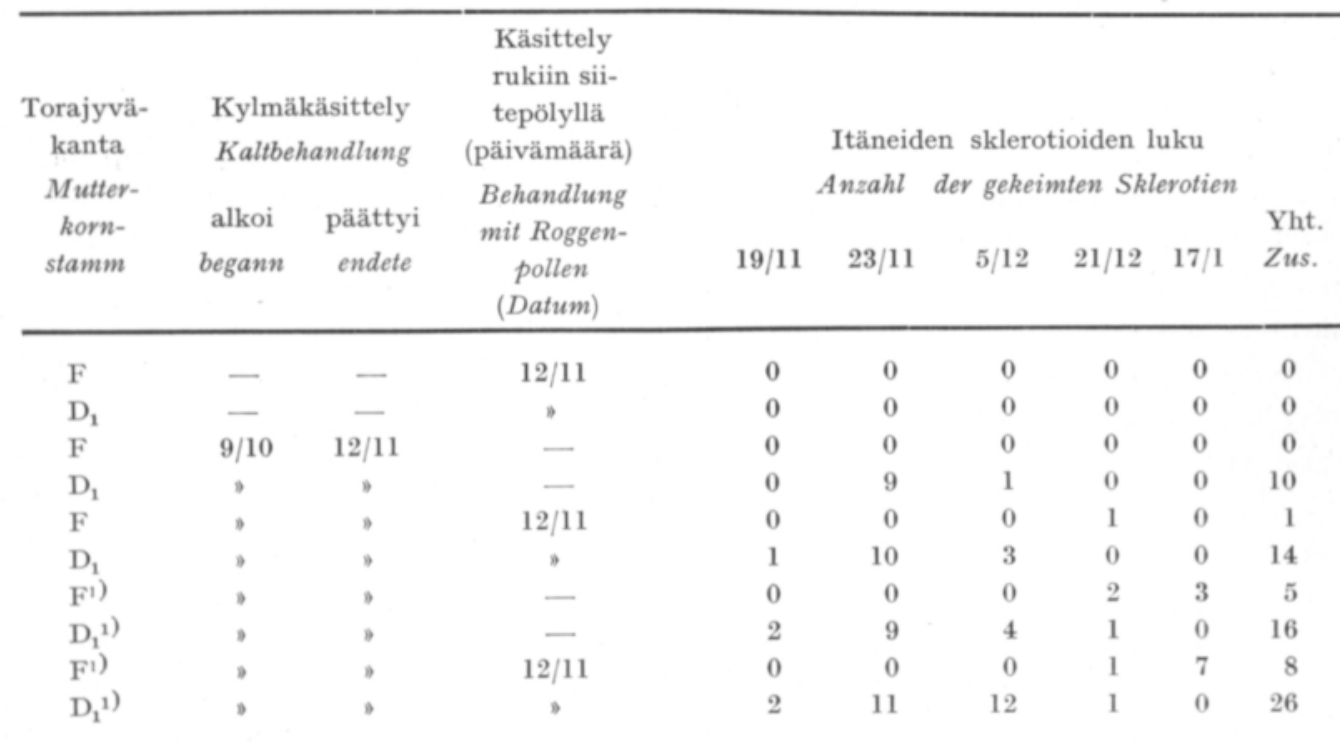

1 Sklerotioita liotettu ennen kylmäkäsittelyä 5 tunnin ajan. Sklerotien vor der Kaltbehandlung 5 Stunden eingeweicht. 
Taulukko 2. $\mathrm{D}_{1}$-torajyväkannan sklerotioiden itäminen v. 1953 (koesarja 2). Sklerotioiden luku koejäsentä kohden $15 \mathrm{kpl}$, idätyslämpötila $18.6^{\circ} \mathrm{C}$. Sklerotioita liotettu ennen kylmäkäsittelyä 18 tunnin ajan. Tabelle 2. Das Keimen von Sklerotien des Mutterkornstammes $D_{1}$ im Jahre 1953 (Versuchsreihe 2). Anzahl der Sklerotien je Versuchsglied $15 \mathrm{St}$. Keimungstemperatur $18.6^{\circ} \mathrm{C}$. Sklerotien vor der Kaltbehandlung 18 Stunden eingeweicht.

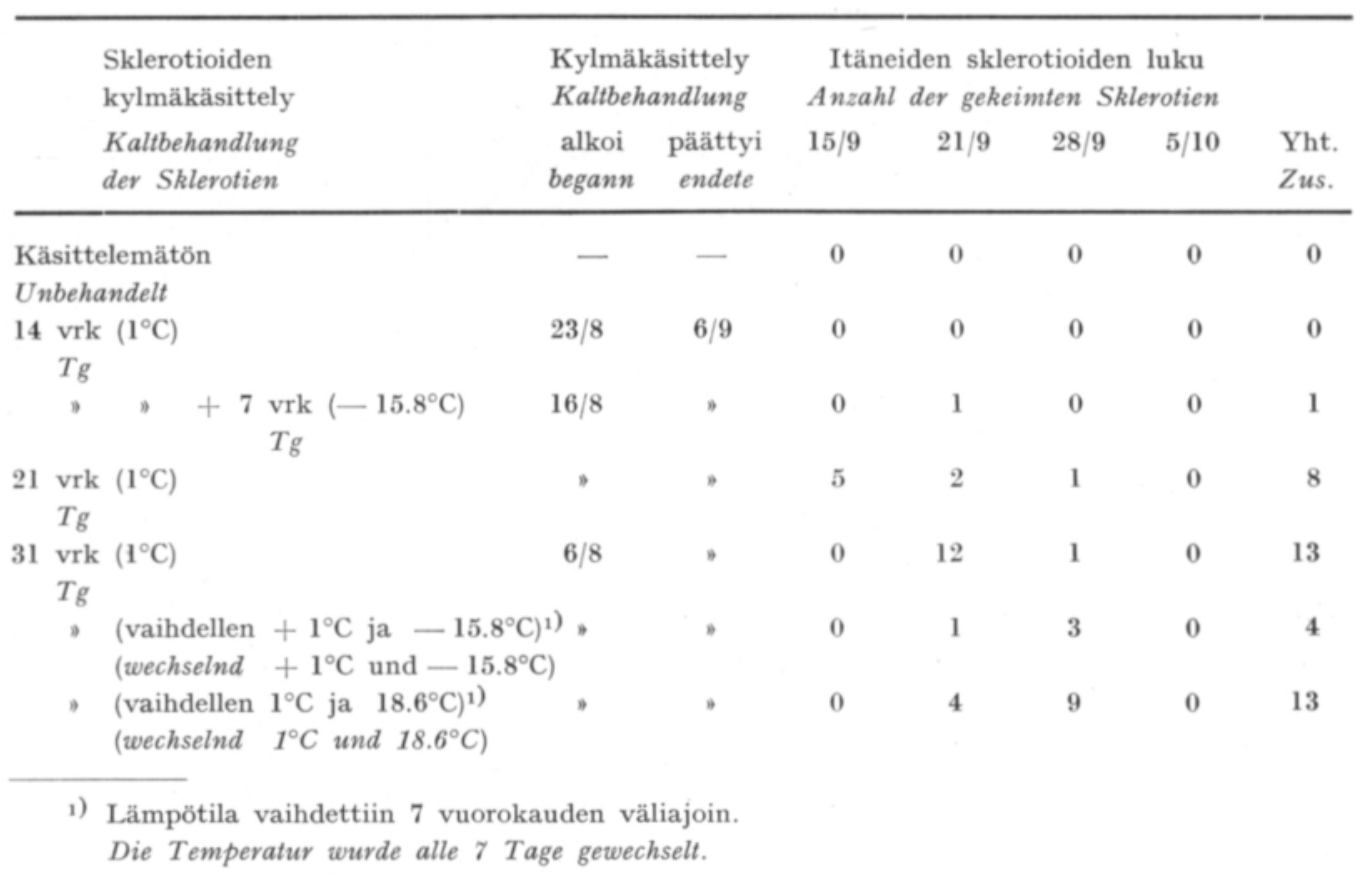

tui termostaattihuoneissa $\left(+1^{\circ} \mathrm{C}\right.$ ja $\left.-15.8^{\circ} \mathrm{C}\right)$ ja idätys laboratoriohuoneessa $\left(18-23^{\circ} \mathrm{C}\right)$, jossa maljat sijoitettiin lähelle suurta ikkunaa.

Yhdessä koesarjassa (koesarja 4) torajyvät peitattiin Täyssato-kuivapeittausaineella (vaikuttava aine org. elohopea). Tällöin käytettiin valmistajan rukiille suosittelemaa ainemäärää. Muissa koesarjoissa torajyviä ei peitattu.

Sklerotioiden itämistä tapahtui vain 1. ja 2. koesarjassa, kun sen sijaan koesarjoissa 3 ja 4 erilaiset homesienet verraten nopeasti peittivät torajyvät, lopulta tuhoten ne kokonaan (vrt. asetelma, s. 224).

Koesarjassa n:o 1 ensimmäiset saksalaisen $\left(\mathrm{D}_{1}\right)$ torajyväkannan kylmäkäsitellyt $\left(1^{\circ} \mathrm{C}\right)$ sklerotiot itivät jo viikon kuluttua idätyksen alkamisesta lukien (taulukko 1). Sen sijaan suomalaisen (F) torajyväkannan sklerotioilla vastaava aika oli n. 5 viikkoa. Sitä paitsi alustapahkojen luku jäi pienemmäksi F- $(2-3 \mathrm{kpl})$ kuin $\mathrm{D}_{1}$-torajyväkannan $(9-15 \mathrm{kpl})$ sklerotioissa. Mikroskooppinen tutkimus osoitti, että molempien torajyväkantojen sklerotioissa muodostuneet stromat sisälsivät kypsiä kotelopulloja. Sklerotioiden itävyys oli 2-52\%. Tämän kokeen perusteella näyttää siltä kuin kotimainen torajyväkanta, sopeutuneena maamme olosuhteisiin, vaatisi pitemmän kuin 34 vrk:n kylmäkäsittelyajan, jota ko. kokeessa käytettiin, saavuttaakseen samanlaisen itämisherkkyyden kuin lyhyempään kylmään kauteen mukautunut saksalainen $\mathrm{D}_{1}$-torajyväkanta. 
Toisessa koesarjassa aiheutti 31 vuorokauden pituinen kylmäkäsittely, niin yhtämittainen kuin jaksottainen (maljat vaihdellen $1^{\circ} \mathrm{C}$ ja $18.6^{\circ} \mathrm{C}$ ), torajyvissä (D-torajyväkanta) jopa $87 \%$ itävyyden (taulukko 2 ). 21 vuorokauden kylmäkäsittelyn $\left(1{ }^{\circ} \mathrm{C}\right)$ seurauksena torajyvät itivät huomattavasti heikommin $(53 \%)$ ja 14 vuorokauden pituisella kylmäkäsittelyllä ei ollut näkyvää torajyvien itämistä edistävää vaikutusta. Pakkaskäsittelyn (maljat vaihdellen $+1^{\circ} \mathrm{C}$ ja $-15.8^{\circ} \mathrm{C}$ ) vaikutus torajyvien itämiseen oli selvästi negatiivinen; sklerotioiden itävyys oli vain $7-27 \%$. Näiden kokeiden perusteella näyttääkin siltä, että kylmäkäsittelyllä on torajyväsientä jarovisoiva vaikutus.

Toisen koesarjan yhteydessä tutkittiin myös laboratoriohuoneessa säilytettyjä, ylivu otisi a sklerotioita $\left(D_{1}\right.$-torajyväkanta); vain eräässä tapauksessa ne itivät, silloinkin heikosti (15 sklerotiosta $2 \mathrm{kpl})$. Vastaava tulos on saatu eräissä ulkomailla suoritetuissa tutkimuksissa (4), mutta tunnetaan myös tapauksia, joissa ylivuotisetkin torajyvät ovat itäneet melko hyvin $(10,22)$.

\section{Rukiin siitepölyn vaikutuksesta torajyvien itämiseen}

Eräiden Saksassa suoritettujen tutkimusten (19) mukaan rukiin siitepölyllä on ärsytysvaikutusta siinä esiintyvän torajyvärodun sklerotioiden itämisessä. Samalle rodulle alttiiden eräiden toisten heinäkasvien siitepölyllä on samanlainen vaikutus. Torajyvien itämistä jouduttava siitepölyn sisältämä aine on todettu biotiini-kasvuainetta muistuttavaksi (19). Myös kasvipatologian laitoksessa tutkittiin rukiin siitepölyn vaikutusta torajyvien itämiseen.

Kokeita varten siitepöly kerättiin rukiista (Petkus- ja Ensi-syysrukiit, koesarjat 1, 3 ja 4), joka orasasteella oli tuotu koekentältä laboratoriohuoneeseen ja istutettu Mitscherlich-astioihin. Siitepölystä valmistettiin suspensio siten, että murskattuja heteiden ponsia sekoitettiin steriloituun veteen; sen jälkeen suspensio ruiskutettiin torajyvien pinnalle. Torajyvien siitepölykäsittely tapahtui välittömästi niiden jarovisoinnin jälkeen.

Rukiin siitepöly kohotti sklerotioiden itävyyden parhaassa tapauksessa $32 \%$ :sta $52 \%$ :in ja samalla joudutti, joskin vain vähän, sklerotioiden itämistä (taulukko 1). Vastoin Schweizerin (19) kokeiden tuloksia todettiin kuitenkin, että sklerotiot voivat itää tyydyttävästi ilmankin rukiin tai muiden Gramineae-lajien siitepölyn stimuloivaa vaikutusta. Niinpä toisessa koesarjassa (taulukko 2), jossa torajyvien siitepölykäsittelyä ei suoritettu, sklerotiot eräissä tapauksissa itivät lähes $90 \%$ :sti.

Torajyvien itämishavaintoja suoritettiin paitsi laboratoriossa myös ulkona. Kesällä 1953 tehtiin torajyvien itämishavaintoja koekentällä (n. $\left.14 \mathrm{~m}^{2}\right)$, joka edellisenä vuonna oli ollut Petkus-kevätrukiin kasvupaikkana, ja jossa ei syyskyntöä oltu suoritettu. Havainnot itäneistä torajyvistä (F-torajyväkanta) suoritettiin sateiden jälkeen. Tällöin sklerotioiden määrästä, $282 \mathrm{kpl}$, oli itäneitä:

$\begin{array}{lrrcccc}\text { p:nä } & 3 / 6 & 4 / 6 & 10 / 6 & 14 / 6 & 10 / 7 & \\ \text { kpl } & 95 & 53 & 55 & 27 & 1 & \text { yht. } 231(82 \%)\end{array}$

$72 \%$ sklerotioista iti ennen havaintopaikan vieressä kasvaneen Petkus-syysrukiin kukinnan alkamista (12. 6.). Samana vuonna Viikin koetilan talousviljel- 
män Ensi-ruis aloitti kukintansa myöhemmin, 19. 6. - Itäneet torajyvät aiheuttivat Petkus-rukiissa ankaran saastunnan; elokuussa sen tähkistä poimittiin torajyviä $81 \mathrm{kpl} / \mathrm{m}^{2}$.

Keväällä 1954 tehtiin vastaavanlaiset havainnot paikalta (n. $40 \mathrm{~m}^{2}$ ), jossa edellisenä kesänä oli ollut Ensi-rukiin torajyväsaastutuskoe (vrt. 17). Saastutuksiin oli käytetty $\mathrm{D}_{1^{-}}$ja F-torajyväkantoja. Tutkitun alan $\left(1 \mathrm{~m}^{2}\right)$ sklerotioista, $109 \mathrm{kpl}$, oli itäneitä:

$$
\begin{array}{lrrcrr}
\text { p:nä } & 4 / 6 & 5 / 6 & 12 / 6 & 15 / 6 & \\
\text { kpl } & 8 & 10 & 18 & 29 & \text { yht. } 65(60 \%)
\end{array}
$$

Havaintopaikan välittömässä läheisyydessa kasvanut Ensi-ruis alkoi kukkia vasta 28/6, eli silloin, kun torajyvien itäessä kehittyneet alustapahkat kotelopulloineen näyttivät jo kokonaan kuihtuneilta. Torajyvien itäminen päättyi kesäkuun 15 päivän tienoilla hyvin jyrkästi, nähtävästi sen vuoksi, että sää muuttui poutaiseksi (13). Otaksuttavasti samasta syystä torajyviä muodostui Ensi-rukiin tähkiin vähemmän kuin Petkus-rukiiseen edellisenä vuonna (1953) suoritetussa kokeessa.

Edellä esitettyjen kahden vuoden aikana suoritettujen havaintojen perusteella on pääteltävissä, että rukiin siitepölyllä ei Suomen olosuhteissa voi olla sanottavaa vaikutusta torajyvien itämiseen. Sen sijaan $C$. purpurean ruista saastuttavalle rodulle alttiit luonnonvaraiset heinät, kuten Anthoxanthum odoratum L. ja Hierochloë odorata (L.) Wg., jotka aloittavat kukintansa jo toukokuussa, voivat siitepölyllään edistää torajyvien itämistä. - Saksassa (14) ja Unkarissa (2) suoritetut tutkimukset viittaavat siihen, että sikäläisissä olosuhteissa torajyväsieni saastuttaakin primäärisesti ruispeltoon rajoittuvia luonnonvaraisia heinäkasvustoja ja ruista vasta sekundäärisesti heinälajien kukinnoissa kehittyvillä kuromillaan. Suomen olosuhteissa tällä saastumistavalla tuskin kuitenkaan on vastaavaa merkitystä, koska useimmat $C$. purpurean ruista saastuttavalle rodulle alttiista luonnonvaraisista heinistä kukkivat vielä myöhemmin kuin ruis. Tästä huolimatta voinee ruispeltoa reunustavien luonnonvaraisten heinäkasvustojen niittämisellä ennen niiden kukintaa torajyvän torjunnassa olla jotain merkitystä meidänkin maassamme.

\section{Maahan upotettujen torajyvien itäminen}

Maahan upotettujen torajyvien itämistä selvitettiin koesarjassa 5, jossa eri torajyväkantojen sklerotioita sijoitettiin peltomaahan (rukiin sänki) 1, 20 ja 50 cm:n syvyyteen, $100 \mathrm{kpl} \mathrm{kuhunkin} \mathrm{syvyyteen.} \mathrm{Koe} \mathrm{aloitettiin} \mathrm{8.} \mathrm{10.} 1953$.

Sklerotioiden itäminen oli runsaampaa 20 kuin $1 \mathrm{~cm}: n$ syvyydessä (taulukko 3 ), mikä otaksuttavasti johtui siitä, että multakerroksen kosteus säilyi tasaisempana syvemmällä kuin lähellä maan pintaa. Alustapahkoihin ei kuitenkaan muodostunut kypsiä kotelopulloja 20 ja $50 \mathrm{~cm}$ :n syvyydessä, ilmeisesti sen vuoksi, että niiden kehitykselle välttämätön valon saanti (vrt. 19) estyi. Syvällä multakerroksen alla muodostuneet stromat olivat muodoltaan epämääräisen litistyneitä; ne olivat yleensä toisiinsa kiinni painuneita. 
Taulukko 3. Eri syvyyksille peltomaahan upotettujen torajyvien itäminen v. 1954. Sklerotioiden luku koejäsentä kohden $100 \mathrm{kpl}$.

Tabelle 3. Das Keimen der verschieden tief in Ackerboden gesteckten Mutterkörner im Jahre 1954. Anzahl der Sklerotien je Versuchsglied 100 St.

\begin{tabular}{|c|c|c|c|c|c|c|c|c|c|}
\hline \multirow{3}{*}{$\begin{array}{l}\text { Torajyvä- } \\
\text { kanta } \\
\text { Mutterkorn- } \\
\text { stamm }\end{array}$} & \multirow{3}{*}{$\begin{array}{c}\text { Syvyys } \\
\text { Tiefe } \\
(\mathrm{cm})\end{array}$} & \multicolumn{8}{|c|}{$\begin{array}{l}\text { Itäneiden sklerotioiden luku } \\
\text { Anzahl der gekeimten Sklerotien }\end{array}$} \\
\hline & & \multicolumn{8}{|c|}{ Päivämäärä (kesäkuun) } \\
\hline & & & 2. & 5. & 10. & 15. & 22 . & 28 . & Zus. \\
\hline F & 1 & & 37 & 11 & 31 & 10 & - & - & 89 \\
\hline , & 20 & & - & - & - & - & 90 & - & 90 \\
\hline$\cdot$ & 50 & $\cdot$ & - & - & - & - & - & 27 & 27 \\
\hline$D_{1}$ & 1 & & 27 & 2 & 9 & 26 & - & - & 64 \\
\hline , & 20 & & - & - & - & - & 91 & - & 91 \\
\hline$"$ & 50 & & - & - & - & - & - & 22 & 22 \\
\hline $\mathrm{D}_{4}$ & 1 & & 22 & 17 & 6 & 13 & - & - & 58 \\
\hline , & 20 & & - & - & - & - & 91 & - & 91 \\
\hline , & 50 & & - & - & - & - & - & 45 & 45 \\
\hline
\end{tabular}

Yhden $\mathrm{cm}$ :n syvyyteen sijoitetuissa torajyvissä stromat kasvoivat maan pintaan saakka; näin ne joutuivat alttiiksi valon vaikutukselle. Stromat olivat vain vähäisessä määrin toisiinsa kiinni painuneita ja muodostivat normaalisia kotelopulloja koteloitiöineen. Suomalaisen torajyväkannan sklerotiot itivät jonkin verran paremmin kuin saksalaisten (taulukko 3). Kuitenkin myös saksalaiset, runsasalkaloidiset torajyväkannat $\left(\mathrm{D}_{1}\right.$ ja $\left.\mathrm{D}_{4}\right)$ muodostivat koteloitiöitä; on siis otaksuttavaa, että nämäkin torajyväkannat voivat säilyä ja levitä maassamme. — Saksalaisen $\mathrm{D}_{1}$-torajyväkannan sklerotiot kehittivät yleensä niin runsaasti rihmastoa, että niiden pinta oli muuttunut valkeaksi; vastaavaan ilmiöön on myös eräissä aikaisemmissa tutkimuksissa $(3,14)$ kiinnitetty huomiota. Lisäksi todettiin rihmastossa selvää kuromanmuodostusta.

\section{Tutkimuksia torajyvissä esiintyneistä muista sienistä}

Aikaisemmat tutkimukset ovat osoittaneet, että torajyvät ovat varsin alttiita muiden sienien, varsinkin hiiva- ja erilaisten homesienien aiheuttamalle saastunnalle $(1,4,8,10,14,15,16,21,22)$. Torajyvistä on näiden tietojen mukaan eristetty mm. seuraavat sienilajit: Fusarium avenaceum (Fr.) Sacc. (11), F. heterosporum Nees (vrt. 21), Trichothecium roseum Link ja Verticillium cylindrospermum Corda (4). Kasvipatologian laitoksen koekentällä suoritetussa idätyskokeessa ei torajyviin ilmaantunut huomattavassa määrin muita sienilajeja. Sen sijaan laboratoriokokeissa havaittiin torajyvissä homeita erittäin runsaasti. Homesienien esiintymisestä tehtiin erilaisia havaintoja; mm. tarkkailtiin, kuinka nopeasti sienet kehittyivät. Monesti esiintyi samassa sklerotiossa kaksi, joskus useampiakin 
sienilajeja samanaikaisesti. Tarkempia tutkimuksia varten sienet aluksi siirrostettiin Petrin maljoihin Henneberg- (7) ja kaura-agarialustoille ja näiltä edelleen samoille alustoille koeputkiin, joissa niiden kehitystä seurattiin jopa useiden kuukausien aikana.

Eräissä laboratoriokokeissa (koesarjat 3 ja 4) verraten korkea idätyslämpötila (keskim. 20.2 ja $22.2^{\circ} \mathrm{C}$ ) ilmeisesti edisti homesienien kasvua torajyvien pinnalla, kun sitä vastoin niissä koesarjoissa (koesarjat 1 ja 2), jotka suoritettiin alhaisemmassa lämpötilassa $\left(18.7\right.$ ja $\left.18.6^{\circ} \mathrm{C}\right)$, sklerotiot säilyivät jokseenkin saastumattomina.

Torajyvien pinnalta, idätysmaljoista, eristetyt sienet kuuluivat sukuihin: Cephalosporium Corda, Fusarium Link, Mucor Micheli ja Trichothecium Link (5). Niiden esiintymisrunsaus, saastuneita (\%) kaikista tutkituista torajyvistä, oli seuraava:

\begin{tabular}{|c|c|c|c|c|c|c|c|c|}
\hline \multirow[b]{2}{*}{$\begin{array}{l}\text { Koesarja } \\
\text { Versuchs- } \\
\text { reihe }\end{array}$} & \multicolumn{3}{|c|}{$\begin{array}{c}\text { Torajyväkanta } D_{1} \text { (Saksa) } \\
\text { Mutterkornstamm } D_{1} \text { (Deutschland) }\end{array}$} & \multirow[b]{2}{*}{$\begin{array}{l}\text { Tricho- } \\
\text { thecium }\end{array}$} & \multicolumn{4}{|c|}{$\begin{array}{c}\text { Torajyväkanta } \mathrm{F} \text { (Suomi) } \\
\text { Mutterkornstamm F (Finnland) }\end{array}$} \\
\hline & $\begin{array}{l}\text { Cepha- } \\
\text { losporium }\end{array}$ & $\begin{array}{l}\text { Fusa- } \\
\text { rium }\end{array}$ & Mucor & & $\begin{array}{l}\text { Homeita } \\
\text { yht. } \\
\text { Schimmel- } \\
\text { pilze zus. }\end{array}$ & $\begin{array}{l}\text { Fusa- } \\
\text { rium }\end{array}$ & $\begin{array}{l}\text { Tricho- } \\
\text { thecium }\end{array}$ & $\begin{array}{l}\text { Homeita } \\
\text { yht. } \\
\text { Schimmel- } \\
\text { pilze zus. }\end{array}$ \\
\hline \multicolumn{9}{|l|}{ 1) } \\
\hline 1 & 0 & 0 & 0 & +++ & +++ & 0 & + & + \\
\hline 2 & 2.3 & 0 & 1.0 & 0 & 3.3 & - & - & - \\
\hline 3 & 0 & 39.5 & 0 & 0 & 39.5 & 41.5 & 0 & 41.5 \\
\hline 4 & 69.7 & 2.1 & 1.8 & 0 & 73.6 & - & - & - \\
\hline
\end{tabular}

Ensimmäisessä koesarjassa Trichothecium-saastunta oli selvästi voimakkaampaa saksalaisen $\left(\mathrm{D}_{1}\right)$ kuin kotimaisen $(\mathrm{F})$ torajyväkannan sklerotioissa.

Torajyvien saastutuskokeita suoritettiin ainoastaan Trichothecium roseumsienellä. Sieni eristettiin laboratoriossa suoritetusta idätyskokeesta, $D_{1}$-torajyväkannan sklerotion pinnalta. 57 vuorokauden ikäisessä kaura-agariviljelmässä rihmasto oli seittimäistä, väliseinällistä, aluksi valkeata, muuttuen vähitellen vaalean punaiseksi. Kuromankannattimet suoraan ylöspäin kohoavia, tavallisesti haarattomia. Kuromat päärynän muotoisia, enimmäkseen kaksisoluisia, muodostuen kuromankannattimien kärjissä. Kuromien koko 9.6-21.7 $\times 4.8-9.6 \mu$ (kuva 2).

T. roseum lienee levinnyt torajyviin kasvipatologian laitoksessa samanaikaisesti kasvatetuista sienen puhdasviljelmistä. Torajyvien idätyskokeessa (koesarja 1) $T$. roseum kasvoi selvästi nopeammin runsaasti alkaloideja sisältävän $\mathrm{D}_{1}$-kannan (20) kuin alkaloidittoman F-torajyväkannan (9) sklerotioiden pinnalla (vrt. asetelma, s. 224). Sitä paitsi eräässä toisessa kokeessa sieni muodosti rihmastoa ja kuromia vähän nopeammin saksalaisen $\left(\mathrm{D}_{1}\right)$ kuin kotimaisen torajyväkannan $(\mathrm{F})$ sklerotioiden pinnalla (taulukko 4). Tällöin vedessä liotetut $(8 \mathrm{t}) \mathrm{D}_{1^{-}}$ja F-torajyvä- 


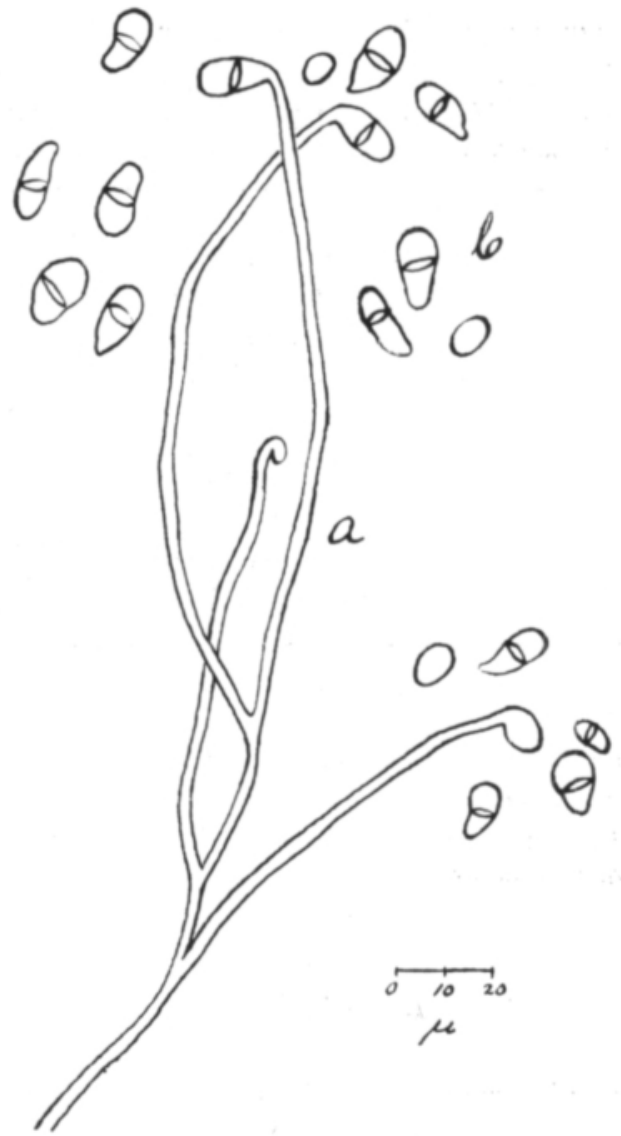

Kuva 2. Trichothecium roseum. a. Kuromankannattimia, b. kuromia 14 vuorokauden ikăisestä Henneberg-agariviljelmästä.

Abb. 2. Trichothecium roseum. a. Konidienträger, b. Konidien von 14 tägiger Henneberg-Agarkultur.

kannan sklerotiot (ikä n. 7 kk.) sijoitettiin autoklavisoidulle kvartsihiekalle Petrin maljoihin huoneen lämpötilaan. T. roseumin kuromat sekoitettiin steriloituun veteen. Tätä suspensiota ruiskutettiin torajyvien pinnalle.

Sklerotioiden alkaloidipitoisuuden mahdollista vaikutusta niiden $T$. roseumsaastunnan alttiuteen tutkittiin kokeella, jossa puolet alkaloidittomista F-torajyväkannan sklerotioista ennen kokeen alkua liotettiin vedessä $(2.5 \mathrm{t})$ ja toinen puoli Ermetrine-nimisessä alkaloidivalmisteessa, joka sisälsi $0.152 \%$ maleas ergometriiniä. Sklerotiot sijoitettiin autoklavisoidulle kvartsihiekalle Petrin maljoihin $\left(18.1^{\circ} \mathrm{C}\right)$ ja saastutettiin $T$. roseumin kuromilla, jotka olivat kasvaneet $\mathrm{D}_{1}$-sklerotioissa. Kummallakin tavoin käsiteltyjä sklerotioita oli 15 . Sekä vedessä että alkaloidivalmisteessa liotetut sklerotiot saastuivat keskenään samalla tavoin. Molemmissa tapauksissa saastuneiden sklerotioiden luku oli 13 ja aika saastutuksesta sienen silmävaraisesti havaittavaan ilmaantumiseen sklerotion pinnalle oli 4 päivää. Tässä, niinkuin muissakin kokeissa $T$. roseum tuhosi sklerotiot täydellisesti. 
Taulukko 4. $\mathrm{D}_{1^{-}}$ja F-torajyväkantojen sklerotioiden saastutus Trichothecium roseumin kuromilla. Sklerotioiden luku koejäsentä kohden $15 \mathrm{kpl}$. Lämpötila $21.5^{\circ} \mathrm{C}$.

Tabelle 4. Infektion von Sklerotien der Mutterkornstämme $D_{1}$ und $F$ mit Konidien von Trichothecium roseum. Anzahl der Sklerotien je Versuchsglied $15 \mathrm{St}$. Temperatur $21.5^{\circ} \mathrm{C}$.

\begin{tabular}{|c|c|c|c|c|c|c|}
\hline \multirow{4}{*}{$\begin{array}{l}\text { Kuromien alkuperä } \\
\text { Herkunft der Konidien }\end{array}$} & \multirow{2}{*}{\multicolumn{2}{|c|}{$\begin{array}{c}\text { Päiviä saastutuksesta } \\
\text { sienen ilmaantumiseen } \\
\text { Tage von der Infektion } \\
\text { bis zum Erscheinen des } \\
\text { Pilzes }\end{array}$}} & \multicolumn{4}{|c|}{$\begin{array}{l}\text { Sklerotioiden luku } \\
\text { Anzahl der Sklerotien }\end{array}$} \\
\hline & & & \multirow{2}{*}{\multicolumn{2}{|c|}{$\begin{array}{c}\mathrm{D}_{1^{-}} \\
\text {sklerotiot } \\
\text { Sklerotien } \\
\mathrm{D}_{1}\end{array}$}} & \multirow{2}{*}{\multicolumn{2}{|c|}{$\begin{array}{c}\text { F- } \\
\text { sklerotiot } \\
\text { Sklerotien } \\
\text { F }\end{array}$}} \\
\hline & \multirow{2}{*}{$\begin{array}{c}\mathrm{D}_{1^{-}} \\
\text {sklerotiot } \\
\text { Sklerotien } \\
\mathrm{D}_{1}\end{array}$} & \multirow{2}{*}{$\begin{array}{c}\text { F- } \\
\text { sklerotiot } \\
\text { Sklerotien } \\
\text { F }\end{array}$} & & & & \\
\hline & & & $\begin{array}{l}\text { Yht. } \\
\text { Zus. }\end{array}$ & $\begin{array}{l}\text { Saastui } \\
\text { Infi- } \\
\text { ziert } \\
\text { wurden }\end{array}$ & $\begin{array}{l}\text { Yht. } \\
\text { Zus. }\end{array}$ & $\begin{array}{c}\text { Saastui } \\
\text { Infi- } \\
\text { ziert } \\
\text { wurden }\end{array}$ \\
\hline Saastuttamaton & - & - & 15 & 0 & 15 & 0 \\
\hline Nicht infiziert & & & & & & \\
\hline $\begin{array}{l}\text { Kuromat } \mathrm{D}_{1} \text {-sklerotioista } \\
\text { Konidien von den Sklerotien } D_{1}\end{array}$ & 47 & 64 & , & 12 & , & 10 \\
\hline $\begin{array}{l}\text { Kuromat Henneberg-agariviljelmästä } \\
\text { Konidien von Henneberg-Agarkultur }\end{array}$ & 27 & 27 & , & 6 & , & 2 \\
\hline
\end{tabular}

\section{$P$ ä $\operatorname{ät}$ el $m$ i $\ddot{a}$}

Kasvipatologian laitoksessa suoritetuissa kokeissa torajyvät eivät itäneet ilman kylmäkäsittelyä. Sekä yhtämittainen $\left(1^{\circ} \mathrm{C}\right)$ että jaksottainen (vaihdellen $1^{\circ} \mathrm{C}$ ja $\left.18.6^{\circ} \mathrm{C}\right) 31$ vuorokauden pituinen kylmäkäsittely aiheutti $\mathrm{D}_{1}$-torajyväkannan sklerotioissa jopa $87 \%$ itävyyden. 14 vuorokauden pituisen kylmäkäsittelyn seurauksena torajyvät eivät itäneet ollenkaan. Pakkaskäsittelyn (vaihdellen $+1^{\circ} \mathrm{C}$ ja $-15.8^{\circ} \mathrm{C}$ ) vaikutus torajyvien itämiseen oli negatiivinen.

Noin kuukauden pituisen kylmäkäsittelyn $\left(1^{\circ} \mathrm{C}\right)$ seurauksena saksalaisen $\mathrm{D}_{1^{-}}$ torajyväkannan sklerotiot itivät kotimaisen F-torajyväkannan sklerotioita nopeammin.

Ylivuotiset, laboratoriohuoneessa säilytetyt $\mathrm{D}_{1}$-torajyväkannan sklerotiot eivät yleensä olleet itämiskykyisiä.

Torajyvien käsittely rukiin siitepölyllä kohotti niiden itävyyden parhaassa tapauksessa $32 \%$ :sta $52 \%$ :iin. Eräässä koesarjassa torajyvät kuitenkin itivät jopa $90 \%$ :sti ilman rukiin siitepölyn stimuloivaa vaikutusta.

Koekentällä torajyvät itivät $0-24$ vuorokautta ennen niiden välittömässä läheisyydessä kasvaneen rukiin kukinnan alkamista. Rukiin tähkät saastuivat myös siinä tapauksessa, että torajyviin muodostuneet stromat näyttivät kuihtuneilta rukiin kukinnan alkaessa.

Peltomaahan, $1 \mathrm{~cm}: n$ syvyyteen sijoitettujen torajyvien itäessä muodostuneet alustapahkat sisälsivät normaalisia kotelopulloja koteloitiöineen; 20 ja $50 \mathrm{~cm}: n$ syvyydessä torajyvät muodostivat surkastuneen alustapahkan. Suomalaisen tora- 
jyväkannan lähes alkaloidittomat sklerotiot itivät jonkin verran paremmin kuin runsasalkaloidisten saksalaisten.

Torajyviin ei koekentällä ilmaantunut huomattavassa määrin muita sienilajeja. Sen sijaan laboratoriokokeissa esiintyi torajyvissä runsaasti erilaisia homesieniä. Näihin kuului Trichothecium roseum Link, joka tuhosi torajyvät lopulta täydellisesti.

Torajyvätutkimuksiin olen saanut arvokasta tukea esimieheltäni, kasvipatologian laitoksen johtajalta, professori Onni Pohjakalliolta. Lausun hänelle siitä parhaat kiitokset.

\section{KIRJALLISUUTTA}

(1) Ано, E. 1953. Torajyvän viljelemisestä Suomessa. Farm. aikak. 5: 115-129.

(2) BÉKÉsY, N. von 1956 a. Uber die technischen und agrotechnischen Fragen der Mutterkornkultur. Pharmazie 11: $339-350$.

(3) $\rightarrow 1956$ b. Ein Beitrag zur Biologie des Mutterkorns. Phytop. Z. 26: $49-56$.

(4) FALCK, R. 1922. Ưber die Bekämpfung und die Kultur des Mutterkorns im Roggenfelde. Pharm. Ztg. 67: 777-779.

(5) Gilman, J. C. 1945. A manual of soil fungi. 392 s. Ames, Iowa.

(6) Неске, L. 1921. Die Kultur des Mutterkorns. Schw. Apoth. Ztg. 59: 277-281, $293-296$.

(7) Henneberg, W. 1909. Gärungsbakteriologisches Praktikum, Betriebsuntersuchungen und Pilzkunde. 670 s. Berlin.

(8) Henson, L. \& Valleau, W. D. 1940. The production of apothecia of Sclerotinia sclerotiorum and $S$. trifoliorum in culture. Phytop. 30: 869-873.

(9) Järvinen, P. A. 1953. Uber die pharmakodynamischen und klinischen Wirkungen des finnischen Mutterkorns. 82 s. Helsinki.

(10) Кırснноғғ, Н. 1929. Beiträge zur Biologie und Physiologie des Mutterkornpilzes. Zbl. Bakt. Parasitenk. 77: $310-369$.

(11) Krrulis, A. 1942. Die mikroskopischen Pilze als natürliche Feinde der Pflanzenkrankheiten in Lettland. Arb. Landw. Acad. Mitau 1: 479-536. (Ref. Z. Pfl. krankh. 52: 549.)

(12) KreBs, J. 1936. Untersuchungen über den Pilz des Mutterkorns Claviceps purpurea Tul. Ber. Schw. Bot. Ges. 45: $71-165$.

(13) Kuukausikatsaus Suomen sääoloihin. Ilmat. keskusl. vuosik. 48.

(14) Mothes, K. \& Silber, A. 1952. Über den natürlichen Befall der Roggenfelder durch Mutterkorn. Pharmazie 7: $310-313$.

(15) Mühle, E. 1953. Vom Mutterkorn. Heft 103: 1-32.

(16) Pohjakallio, O., Salonen, A., Ruokola, A-L. \& Iкӥнermo, K. 1956. On a mucous mould fungus, Acrostalagmus roseus BAINIER, as antagonist to some plant pathogens. Acta agr. scand. 6: $178-194$.

(17) Ruокоц., A-L. 1956. Torajyvän viljelykokeista Viikin koetilalla ja eräillä kasvinviljelyskoeasemilla Suomessa. (Referat: Uber Anbauversuche von Mutterkorn auf dem Versuchsgut Viik und an einigen Versuchsstationen für Pflanzenbau in Finnland.) Maatal. tiet. aikak. 28: $203-222$.

(18) - 1957. Torajyväsienen, Claviceps purpurea (FR.) TUL:n leviämisestä ja torjunnasta. [Referat: Ưber Ausbreitung und Bekämpfung des Mutterkornpilzes, Claviceps purpurea (FR.) TUL.] Ibid 29: 82-91. 
(19) Schweizer, Gg. 1941. Uber die Kultur von Claviceps purpurea (TUL.) auf kaltsterilisierten Nährböden. Phytop. Z. 13: $317-350$.

(20) Silber, A. \& Bischoff, W. 1954. Die Konstanz des Alkaloidgehaltes bei verschiedenen Rassen von Mutterkorn. Pharmazie 9: 46-61.

(21) Wollenweber, H. W. \& Reinking, O. A. 1935. Die Fusarien, ihre Beschreibung, Schadwirkung und Bekämpfung. 355 s. Berlin.

(22) Zimmermann 1906. Ergänzende Versuche zur Feststellung der Keimfähigkeit älterer Sklerotien von Claviceps purpurea. Z. Pfl. krankh. 16: 129-131.

REFER A T :

UBER DAS KEIMEN VON SKLEROTIEN DES MUTTERKORNPILZES CLAVICEPS PURPUREA (FR.) TUL.

\author{
ANNA-LiIsa Ruokola \\ Pflanzenpathologisches Institut der Universität Helsinki, \\ Versuchsgut Viik
}

Die Mutterkörner haben ohne Kaltbehandlung nicht gekeimt (Tabellen 1 und 2). Sowohl eine ununterbrochene $\left(+1^{\circ} \mathrm{C}\right)$ als auch eine periodische (abwechselnd $+1^{\circ} \mathrm{C}$ und $+18.6^{\circ} \mathrm{C}$ ) einmonatige Kaltbehandlung bewirkten bei Sklerotien des deutschen Mutterkornstammes $\left(\mathrm{D}_{1}\right)$ eine bis zu $87 \%$ ige Keimfähigkeit (Tabelle 2). Eine 14tägige Kaltbehandlung $\left(+1^{\circ} \mathrm{C}\right)$ war zu kurz, um das Keimen von Mutterkörnern zu verursachen. Die Einwirkung von Frostbehandlung (abwechselnd $+1^{\circ} \mathrm{C}$ und $-15.8^{\circ} \mathrm{C}$ ) auf das Keimen von Mutterkörnern war negativ. Eine 34tägige Kaltbehandlung $\left(+1^{\circ} \mathrm{C}\right)$ steigerte das Keimen von Sklerotien des deutschen Mutterkornstammes $\left(D_{1}\right)$ mehr als von denen des finnischen (F) (Tabelle 1; Abb. 1).

Die überjährigen, im Laboratoriumsraum verwahrten Sklerotien des deutschen $\left(\mathrm{D}_{1}\right)$ Mutterkornstammes waren im allgemeinen nicht keimfähig.

Die Behandlung der Mutterkörner mit Roggenpollen steigerte ihre Keimfähigkeit bestenfalls von 32 auf $52 \%$ (Tabelle 1). In einer der Versuchsreihen keimten jedoch die Mutterkörner bis zu $90 \%$ ig ohne den stimulierenden Einfluss von Roggenpollen (Tabelle 2).

Auf dem Versuchsfeld keimten die Mutterkörner 0-24 Tage vor Blütenbeginn des in ihrer unmittelbaren Nähe gewachsenen Roggens. Die Roggenähren wurden auch in dem Falle infiziert, dass die an den Mutterkörnern entstandenen Stromata schon bei beginnender Roggenblüte verdorrt erschienen.

Die Stromata, die sich beim Keimen der in Ackerboden, in 1 cm Tiefe gelegten Mutterkörner gebildet hatten, enthielten normale Asci nebst Ascosporen; in 20 und $50 \mathrm{~cm}$ Tiefe bildeten die Mutterkörner ein verkümmertes Stroma. Die Sklerotien des alkaloidlosen finnischen Mutterkornstammes keimten etwas besser als die der alkaloidreichen deutschen (Tabelle 3).

Im Versuchsfeld erschienen an den Mutterkörnern nicht in beträchtlichem Masse andere Pilzarten. Dagegen kamen in den Laboratoriumsversuchen an den Mutterkörnern in recht reichlichem Masse Schimmelpilze vor. Zu diesen gehörte Trichothecium roseum Link (Abb. 2), das schliesslich die Mutterkörner völlig vernichtete (Tabelle 4). 